\title{
Releasing the Voices Historicizing Colonial Encounters in the Pacific
}

\section{Peter Hempenstall}

Historians are doing it tough today. For the first thirty years after World War II they were accustomed to dealing in empirical realities, constructing typologies of empire, analyzing discrete processes of social and political change, painting word portraits of the human actors engaged in the great confrontational dramas of empire. Or they were flexing ideological muscles, taking on imperialism as an economic and political idea, tying Third World development into world systems, and tracing the genealogies of national independence movements. The field was seemingly theirs by common assent, cozy, and not much contested.

But the 1980s began an unsettling period as a range of new, influential discourses percolated through an increasingly angst-ridden profession. Appropriation of the Other; discursive strategies of power; hegemonial textualizations; the politics of representational practices — these phrases have developed in the 1990s as the typical currency of exchange in symposia and monographs about colonialism. Discussion has left behind the study of colonialism as a clearly demarcated, historical object, a "thing," and moved into the realm of the meanings embedded in texts about colonial relations. The work of historians has been overshadowed by historical anthropologists, literature critics, and cultural studies scholars. Their highly theorized texts delight in deconstructing the authority of traditional positivistic narratives of history. ${ }^{1}$ The politics of scholarship permeates everything that is written and how it is written: the fear of continuing colonialisms in narratives built around Western power, always threatening to reproduce relations of dominance, outsiders still controlling the production of knowledge about the colonized world. Authors can no longer escape the self-consciousness that goes with this incessant demand for reflexive, self-critical history. They are pursued by post- 
modern philosophies that proclaim the flimsiness of reality, the "death of the subject," and the centrality of the text. All these developments have taken their toll on the confident narrative writing that was the hallmark of the historian.

The juggernaut has not proved totally irresistible. The newer discourses are themselves charged through with internal debate about their potential and their limitations. Dissenters point to the tendency to generalize and homogenize colonialism, to see it and its agents as "an abstract force, as a structure imposed on local practice. The terms colonial state, colonial policy, foreign capital, and the white enclave are often used interchangeably, as if they captured one and the same thing" (Stoler 1989:135). It is all too easy to speak of the "Other," "settler societies," "the German empire," and so on without interrogating the diverse lineaments of each, where and when they operated. A restricted range of evidence suffices in order to make sweeping statements, so that theory triumphs over heterogeneity, interpretive wholism rides roughshod over empirical diversity. Another danger is that the new theorizations about colonialism are composed of an interdisciplinary hotchpotch, a wildly intersecting set of discourses claiming equal validity, a situation that can lead to a "relativist permissiveness" that is disabling in its failure to judge among their explanatory power (Thomas 1994:19). At the end of the day, the historical experience of colonial encounters "gets lost in the elegant new textualism of colonial discourse studies" (Dirks 1992:175).

Historians of colonialism therefore need not be nervous about their craft's credibility. They remain in a position to reassert history's particular forms of textualizing the human past, for it exerts a power to story human lives that can be a form of critical action against continuing colonialisms. "Story" is the important concept here. For though historians have traditionally clung to a belief that the texts they create are bound, through the evidence they use, to a material world that defies those texts, they are also sensitive to the power of the texted narrative to make meaning for humans. They are generally therefore loath to stray too far from linear narratives that constitute the explanatory structures of their discourse upon the world. They share Michael Taussig's view that "people delineate their world... in stories and storylike creations and very rarely, if ever, in ideologies" (Taussig 1984:494). ${ }^{2}$

At the heart of these operations is the belief in what Richard Campbell calls "the historicity of human being" (Campbell 1993:7). By this 
he means that humans constitute themselves through and by means of their actions in finite, situated contexts. "Human being is a selfmaking or self-constituting process" (8), not in the sense of selfconsciously creating an individual self or image (which is a modern, Western concept), but as a dialectical-or better, dialogic-process in which humans are challenged to realize freedom in their own unchosen contexts by engaging in a never-completed dialogue between "finitude, naturally and historically given, and the potentially infinite possibilities which can be entertained in thought." ${ }^{3}$

This is the focus of the historian's intellectual-and emotionalactivity: to attempt to describe this engagement in all its richness of possibility and its poverty of failure. The knowledge produced is not about empirical objectivity, but rather epiphanal in quality, disclosing, as the Australian historian Charles Manning Clark puts it, answers to the deeper questions of life by knowing more about the past, "the mystery at the heart of things" (1976:44). By that very fact, it is personal to the historian's sense of self and to the structures of conditioning that shaped the values he or she puts upon the world. "For history cannot be told without expressing the historian's view of what makes for human flourishing, its glories and its failures" (Campbell 1993:10).

Such a description of the historian's task, though itself culturally situated, does not confine the legitimacy of historical analysis to one culture only. It can deal with infinite varieties of human experience because it proceeds from a notion of unfixed, dynamic human nature (Campbell 1993:12). People act out their attempts at "radical selftranscendence" (which may not have anything to do with the concept of the autonomous self) in dialogue with their own historically situated cultural context. Of course, processes in self-understanding differ from culture to culture and need to be taken into account. We must "listen to the voices of those others, and try to hear them in their otherness," writes Campbell, "if the 'horizon of meaning' within which they speak is to extend and become fused with our own" (13).

For Pacific historians of colonialism, these possibilities built into the discipline can mesh productively with the insights of the newer discourses, with their changed angle of interrogation. The emphasis by anthropologists, especially, on colonialism as a cultural process encoded with signs, metaphors, and narratives and powered by interlocking networks of knowledge and power is suggestive of a much denser framework of interpretation. Nicholas Thomas has most re- 
cently summed up this approach by describing colonialism as a "project," a concept that "draws attention not towards a totality such as a culture, nor to a period that can be defined independently of people's perceptions and strategies, but rather to a socially transformative endeavor that is localized, politicized and partial, yet also engendered by longer historical developments and ways of narrating them" (Thomas 1994:105).

History's discourse is well placed to deal in this currency, for history has a refined power of storytelling about complex, contexted encounters between human beings and their situations. History recognizes there are no neat boundaries defined by the will and intention of colonizers on the one hand, and clear perspectives and actions of the colonized on the other. Instead there are a series of "messy entanglements" ${ }^{4}$ within colonizing and indigenous communities and between them, back and forth, that encompass unities and cleavages, alliances and conflicts, contradictions and adaptations, half-successes and failures, willful action and misread responses. Colonial life was, to paraphrase Henry James, all inclusion and confusion. It is art that discriminates and selects.

History's gift is, paradoxically through this art, to pluralize colonialism's existences and its meanings for both then and today. It avoids reducing colonialism to totalizing formulas about the exact nature of power relations and the systems of dominance and resistance that constitute its operations. It describes and analyzes messy encounters, highlighting moments of unpredictable, rolling drama and performative confrontations. For, as Dening argues, encounters with otherness in the Pacific are occasions of theater, wherein language and gesture, European charades, and Islander mimicry are played out in complex and ambiguous relationships (Dening 1992:4).

Historians excel in exploiting the moment of greatest display. Once, that meant fixing on the elite actors at the front of the stage, making them bear the weight of explanation for the history of colonialism. If older fashioned colonial history marched with the European proconsuls and missionaries, the newer anticolonial history simply reversed the polarities and raised up Islander chiefs and Big Men as the new, empowered agents of history. But agency itself has been subverted and converted into a much more "messy" concept. David Chappell has shown how active agency and victimhood work together in overlapping ways that increase the messiness of historical encounters: "Victims need not be passive, nor the passive weak, nor actors free 
agents, for history to happen" (Chappell 1994:10). The real challenge for Pacific historians, says Chappell, is to be aware of the contradictions of agency within our narrative histories, to work in a " 'middle ground' of interaction in cross-cultural situations, a contested but functioning discourse of partial understandings that allows groups in contact to negotiate their relationships" (11-12).

Of course, Pacific historians still have to choose and create their narratives, which always run the risk of perpetuating vastly unequal power relations with colonized communities. Representations of encounters with humans from other cultures that are constructed around the passing of our Western kind of time are filled with power that may unconsciously serve political ends. Outside accounts can control knowledge, both there and here, by speaking for Islanders, by locking them into value-laden categories as exotic if modern agents, functioning on another plane of existence from rationalist, chronologyplotting westerners. Historians may be seeking confirmation of their ideological concerns or pursuing a more personal politics. Johannes Fabian asserts that "our ways of making the Other are ways of making Ourselves. The need to go there (to exotic places, be they far away or around the corner) is really our desire to be here (to find or defend our position in the world)" (1991:209).

We may wish to feel some kind of union with other cultures, searching for it in island cultures today during fieldwork. But there is always a gap between the sympathy that unites and the Western analytical tendency to stand at a distance from the object to be known in order to understand it. Barry Hill, speaking through a personal confrontation with Australian Aboriginal society, argues that the history of colonialism lies between these two poles (1993). So, I would argue, does the historying of colonialism.

There are thousands of "stories" underpinning colonialism, thousands of ways historians and others have constructed the native through their texts. One of the most consistent historiographic examples in the Pacific is the colonial history making that has gone on around the Samoan people. Samoans have been appropriated by scholars as the exemplary Pacific community caught up in the history of Western imperialism. Their islands drew the three Great Powers of the late nineteenth century—Britain, Germany, and the United States-into a contest for economic and diplomatic control that almost ended in war. 
Though the islands were partitioned in 1899 between Germany and the United States, the Western Samoans never accepted the situation and fought a sustained war of political resistance against the Germans and then the New Zealanders, until their group gained independence as the Pacific's first modern nation-state in 1962 (Masterman 1934; Keesing 1934; Davidson 1967; Kennedy 1974; Field 1984; Hempenstall and Rutherford 1984).

Traditionally, a central place in this story goes to the movement of noncooperation and alternative government of the 1920s and 1930s known as the mau. This struggle against the New Zealand colonial administration, which involved large numbers of Samoans (though not all), has become part of the myth of political nationhood, in particular the events of Black Saturday, 28 December 1929. An unarmed Samoan crowd was fired upon by New Zealand police, killing eleven Samoans including Tupua Tamasese Lealofi III, a "royal" chief and one of the leaders of the movement. In Tamasese's dying words to keep the peace, Samoans received the rallying cry of their independence movement.

Tales of the mau usually have embedded within them, as part of the movement's genealogy, an earlier movement of resistance-Lauaki Namulau'ulu Mamoe's man e pule of 1908-1909. Lauaki was from Safotulafai in Savai'i and was generally acknowledged as Samoa's greatest orator chief of the nineteenth century. His organizational skills and rhetoric were at the heart of campaigns to find a "royal" leader for Samoa who would give the Samoan islands stability in the face of encroaching European pressure for annexation. Historical storytellers, both European and Samoan, have dwelt upon Lauaki as a romantic rebel, the real mischief-maker of Samoa, a man of "a thousand tongues" (Braisby 1932-1933:1:21) with no love for the papalagi, the white-skinned strangers who burst from the clouds. When the Germans annexed the western islands he would not submit. He became the controlling figure of a resistance movement that was the direct precursor of the national independence movement of the interwar period. The mythic tale runs broadly as follows.

Lauaki, whose whole life revolved around political activity, was not prepared to accept the role of spectator forced on him by the German governor Wilhelm Solf. Lauaki resented Solf deeply for suppressing the great cartels of orator chiefs, Tumua and Pule, which had traditionally controlled the contest for the four highest titles between the leading "royal" families, Sa Malietoa and Sa Tupua. Pule 
was the confederation of talking chiefs based on Savai'i districts and the island of Manono; Tumua was based on Upolu districts. Though his support had been crucial to Samoans' acceptance of Mata'afa Josefo of the Tupua lineage as holder of the high titles in 1899-1900, Lauaki was at heart a Malietoa man, and he looked to the day when a Malietoan should succeed to the apex of Samoan politics. When Solf was absent on leave in 1908, Lauaki took the opportunity to construct a united front of chiefs to bring Tumua and Pule back to the center and work for a Malietoa candidate to succeed Mata'afa. When Solf's deputy, Schultz, learned that Lauaki wanted a crowd of Samoans to meet Solf on his arrival back and put their requests (mau) en masse for a restoration of the old power brokers, he forbade Lauaki to go to Apia.

Lauaki could not afford to lose such face and continued to mobilize the most important political districts of Samoa by capitalizing on his own status as the leading orator chief of Safotulafai in Savai'i and the virtual spokesman for Pule. He traveled anyway to the main island but lodged himself outside Apia until Solf returned and ordered him back to Savai'i.

The first of two personal confrontations with Solf took place in Safotulafai in November 1908, where Solf warned Lauaki of the vengeance of Germany. The second occurred in Vaiusu, not far from Apia, where Solf and his aide de camp met Lauaki surrounded by hundreds of his war-blackened supporters. In the trading of impassioned speeches, Lauaki turned the tables on Solf, accusing Mata'afa of being the evil genius behind the movement and begging forgiveness for his own ignorance. Solf could take no action without compromising his paramount chief and inflaming a war between Samoan parties. A stalemate ensued, broken only when Solf lost hope he could control the situation and called on the German navy for help. Cruisers arrived after six weeks of tension and only delicate negotiations prevented Lauaki and his supporters taking to the bush to begin a guerrilla campaign. On 1 April 1909 they surrendered to the Germans and some seventy Samoans-Lauaki, his closest supporters, and their families-were promptly exiled to Saipan in the German Mariana Islands in the North Pacific. There they remained until released by Japan and New Zealand in 1915. Lauaki failed to see his home shores again, dying of dysentery in Tarawa on the return journey.

This story is the product of a number of accounts controlled by the colonizers. In each Lauaki is a device in a historiographical agenda 
driven by the political economy of contemporary questionings. German governor Wilhelm Solf, Lauaki's adversary in 1908-1909, began the process in a running collection of reports, essays, and letters stretching over several years. His explanation to Berlin in 1909 of what the mau e pule was all about sets the tone (10.5.09, file 30, Solf Papers; Braisby 1932-1933:2:123-220). This report creates a very coherent account of a highly structured encounter. Lauaki is a formulaic creature of culture, locked into rebellion for reactionary ends. $\mathrm{He}$ had Solf trapped in their two great confrontations. At Safotulafai, Solf found "a large majority—alone nearly the whole of Fa'asaleleaga -taking Lauaki's side and ready to follow him anywhere" (Braisby 2:130). Solf had the courage to call him a liar and an agitator, but it was impossible without military assistance to arrest Lauaki from out of the middle of his followers and bring him to Apia. Lauaki was the great orator and statesman of Samoa, whispered to be gifted with mana.

Vaiusu, according to Solf, was the climax of this personal trial of strength. Again Lauaki controlled the situation, asking Solf to wait for the people of Tuisamau to foregather, clearly drawing Solf's attention to the number of his supporters. His speech on this occasion was, Solf admitted, "a masterpiece of Samoan rhetoric and diplomacy" (Braisby 2:136), painting himself as the unwilling tool of Mata'afa's intrigues and daring Solf to humiliate the old chief in front of such an emotionally charged audience. Solf's reply, as he told a senior colleague in the Colonial Department, could only take the high road of gubernatorial authority in order to outmaneuver Lauaki. He accused him of being "a contemptible coward" (Solf to Schnee 3.6.09, file 131, Solf Papers) and warned him that punishment was unavoidable. He could, said Solf, hear the young men outside practicing their war cries and chided Lauaki that such impoliteness was un-Samoan. Immediately it was still and, observing the working of his speech, Solf seized the moment melodramatically to tear up a letter from Lauaki that Solf had interpreted as a declaration of war. It was, he implied, enough to allow him to escape, and he made Lauaki swear his oath on the Bible that he would send his followers back to Savai' $i$ and remain peaceful.

Solf's report is a retrospective creation caught up in the self-justificatory discourse of Germany's colonial politics, a weapon in Solf's hands against criticism in the German media and against pressure for changes in Samoa coming from European settlers; Lauaki ironically saves Solf's governorship. It is also part of Solf's mythmaking about 
himself. Solf is colonial superman, who beards the clever but inflexible native in his den and by skillful diplomacy escapes triumphant-a more successful General Gordon of Khartoum. As such he is deserving of political reward, on which Solf, like all colonial governors, always had one eye fixed. The reward came extravagantly in 1910, when Solf was made minister for colonies in the kaiser's Germany.

Contemporary colonial politics continued to determine the lines that the Lauaki story would take from the past into the present. In the struggle with the mau in the interwar period, it was imperative for the New Zealand government to show the League of Nations-as well as convince itself-that opposition to its colonial rule was wrongheaded and illegitimate. That task was performed repeatedly, by blaming the Samoans themselves for causing the devastating deaths that the flu pandemic of 1919 wreaked among the population (Tomkins 1992), by punishing dissent through bannings, exile, and the stripping of titles, and by dismissing the local complaints that emerged from the hearings of the Royal Commission into the administration in 1927. A particular prehistory of the mau was constructed by A. L. Braisby, the New Zealand inspector of police during the time of the mau. In 1932-1933 he compiled a set of documents from German and New Zealand sources to show the organic connection between Lauaki's movement of 1908 and the mau. This collection, and Braisby's interpretive comments, were designed to prove that New Zealand was dealing with an irrational movement in the 1920s, driven by the same stone age tendency that drove Lauaki- "the Samoan national trait to periodically rise in political upheavals every 5 or 10 years" (Braisby 1:37). Because the Samoan was "petrified in his notions that are born with him and die with him" (Braisby 3:336), Lauaki and those who came after him were incapable of imagining a new stage of political life. Braisby's extraordinary three-volume effort is a clear exercise in defense of New Zealand, and of himself as police chief, during the clash in 1929 that led to Samoan deaths.

The most recent and detailed story of Lauaki's movement is my own (Hempenstall 1978:55-64). It presents Lauaki the resistance fighter struggling to come to terms with a formidable new concentration of colonial power under the Germans. He represented a tragically attractive figure for me, an echo of the kind of protests I had witnessed during my student days, in an atmosphere of struggle over civil liberties, of student revolution on the German campuses where I studied, and of anti-Vietnam War protest generally. Lauaki appeared the per- 
fect parallel to the giants of West and East African resistance I was made aware of during my studies in Commonwealth and African history. I went looking for him to demonstrate that a variety of resistances to colonial rule-from everyday protests to formal movements - ran like a thread through the history of German colonial empire, and also that the Pacific Islands' story of colonialism had its own peculiar plotlines compared to Africa and Asia.

All these accounts characterize the mau e pule as a contest between two giant protagonists in History, Lauaki and Solf. Both are stylized figures representing their cultural groups. In the stories by papalagi, Lauaki particularly emerges as a cardboard cutout, seemingly voiceless representative of "the Samoan type" rather than a complex and interesting human being. He must needs carry a heavy burden of explanation for the mau e pule: confident, clever, slightly sinister, and ultimately inflexible, Lauaki is the key sign of Samoan rebelliousness; the whole event, the story.

The repetition of the story down the years in mainstream history making about Samoa has continued a tendency to colonize the Samoans via the Western imagination. The mau e pule and Lauaki's role in it have been absorbed into History, which reduces colonialism to a monolithic institution, a thing of blacks and whites. Entanglements are straightforward, reducible to set-piece contests between elite agents. Dramas are melodramas, the actors easily recognizable in their cultural costumes. Any account of "radical self-transcendence" is focused on Europeans, whom we "understand." Lauaki's "historicity as human being" is veiled, his identity shrouded in whispers and rumors, the nature and extent of his agency a constant riddle.

This may be ultimately the price we pay as Western tellers of stories about complex intercultural encounters. As Albert Wendt asserts, the papalagi [or Outlanders] can write about Samoans but not from inside them (Wendt 1987:89). At best we can strain for that gap between identification and distance wherein the history of the colonized can be told. How to write in that gap is one of the problems with which the waves of critical theory confront the historian of the 1990s, by making us aware of the controlling power of representations derived from generations of repeated interpretations. One answer to the problem-and it is only one of several-is to break down the History into a plurality of ambiguous histories by rereading with a new self-consciousness, and a renewed awareness of their embedded politics, the evidences from which the dominant texts take their cue. Reexamine 
the moments of greatest display and look beyond the self-chosen elite players. Strive to release the voices of others (in however a mediated fashion), express their multiple dramas, and increase the density of the historian's contexted encounter.

When Solf and Braisby and Hempenstall-and their sources-are reread in this spirit, they are seen to contain a series of puzzles about Lauaki's behavior and a multitude of other voices beside Solf's and Lauaki's. These suggest a more baroque quality to their encounter and an atmosphere of open possibilities not conceded in the seamless History. The efficient Germans lodged an array of enclosures with their reports to Berlin, of diverse nature and origins, some of them letters from Samoans, some the transcripts of interviews, even the occasional photograph. A rereading of this documentation is capable of producing a cast of thousands who mute Lauaki's strident tones.

But we must see them, or hear them. Historians and storytellers are drawn to giant actors, easily identifiable personalities, those highly individualized figures policed in community memory and in the records. If we reread these records pretending that someone like Lauaki does not exist, then we discover a much wider cross-section of Samoan elites emerging from the pages to harass the German administration and resist Solf's plans to reshape the power structure away from traditional Samoan groups toward German controlled elites. The thousand tongues Lauaki was accused of possessing were actually the uncontrollable, ambivalent voices of many Samoan chiefs and the din of the villagers surrounding them.

Mata'afa himself is clearly implicated. Though presented in History (including my own) as a distant figure quickly growing irrelevant to the colonial history of Samoa, Mata'afa emerges strongly from a rereading, possessed of an active record of challenging German policies, even as they acknowledged him the paramount chief of their protectorate. In 1900 he ignored Solf's instructions to balance the native Samoan administration with chiefs from outside his own party. $\mathrm{He}$ wrote what Solf termed "a series of improper letters" (Braisby 1:17), trying to bully Solf into recognizing Mata'afa's victorious party (malo) as the legitimate government cooperating with-not subordinate to — the German Reich; he tried again in 1904, attempting to extract financial information about the administration and higher salaries from Solf. Mata'afa was also the figurehead and active agent of the attempt the same year to form an indigenous copra cooperative to compete with the large companies. In January 1905 he and the chiefs 
of his malo dispatched a petition to the kaiser complaining that Solf was discriminating against a legal Samoan venture (Hempenstall 1978:45).

The man e pule appears matter-of-factly out of Mata'afa's sorrow for the loss of his power and Solf's downgrading of the "royal" titleholders. And from the beginning it involved whole districts and the ghosts of great chiefs. Lauaki was quite specific on this point and even claimed to have rebuked the old Mata'afa: "What are you crying about? Was it not you who were instrumental in breaking the power of the old Government at Mulinu'u? Of the Ta'imua and Faipule who have gone, none passed away satisfied with the manner in which you had condemned the Government which sat here in former times" (Braisby 3:281-282). It was on the strength of Mata'afa's urging that Lauaki arranged for leading chiefs of many districts to assemble in Apia to greet Solf with his new wife. The ostensible purpose was to offer gifts, but-Lauaki was candid-they hoped to have an opportunity to submit Mata'afa's proposal that his malo, banned from Mulinu'u since 1905, be returned there with full honors. "The Governor was the father of Samoa," said Lauaki, "and he might feel disposed to accede to our wishes" (282).

When Lauaki learned from Schultz that he was not to proceed to Apia, he found himself in a dangerous place. Lauaki had gone ahead to plan with the permission of the district administrator on Savaici, the Irishman Richard Williams. "If the matter were to fall through at that stage, we would become the laughing-stock of all Samoa, and our people would be made the subject of jests about 'Savaii and the presents" " (Braisby 3:286); if they were turned back now it would look like they were planning a demonstration. The pressure on Lauaki was collective, the dignity of his district's people in the balance. It was so great that he set off for Apia anyway, accompanied by longboats crowded with supporters.

The following account of proceedings by Lauaki himself lies quietly among the European documents and has rarely found its way into the dominant records of that event. It is the transcript of a statement Lauaki made to Williams at Fagamalo, Savai'i, a month before his exile (file 30, Solf papers; copy in Braisby 3:274-303). Ostensibly it is about the causes of Lauaki's mau. Though the account begins with Solf's return to Samoa in November 1908, the first part deals not at all with the man e pule but with a ceremonial journey (malaga) by Lauaki and people from his district to districts and villages on Upolu, 
explaining the malo's actions and exhorting people not to think back to olden times.

I then left for Siumu, on my way to Falealili. On arriving at Siumu, I was asked by the people how the government was progressing, and to what extent our own methods of doing things had been affected. I replied that the reason our own power had suffered was that the Faipules agreed to whatever proposals the Governor chose to make. At the same time, however, I said that I thought we were fortunate, on account of the fact that the new power had been so kind to the Samoans. The government was not strongly established, and it was not too hard on the Samoansexcept in respect of those who committed offences; and that had the effect of ensuring that offenders would be punished and brought to realize the power of the law.

We left Siumu for Vaovai, Falealili, where the people laughed at us and joked about the trifling things we had brought over from Apia. The government was not discussed at all.

From Vaovai we went to Lotofaga, but no mention was made of the laws of the government. (Braisby 3:278)

In Siumu the tour was caught up in crisis "as the result of a man from our malaga party eloping with a married woman belonging to the village" (278). Angry villagers damaged Lauaki's canoes, which led to repeated arbitration and the presentation of fine mats to a reluctant Lauaki, who accepted responsibility for his party's delinquency.

What emerges from this story is a dynamic local politics broader and more complex than the issues between Samoans and the colonial community, concerned more with village stability, relative status, and ceremonial reciprocity than with the niceties of colonial power sharing. Lauaki disappears into the background of this much denser encounter. Other voices share front of stage-those of Alipia, Toelupe, Lelei, Ti'a, Solia, and Faumuina, chiefs chosen as deputies (Faipules) by Solf; Onofia, Talouega, and Tuatagaloa of Satale, Alapapa of Tafitoala, and Taoa and Lutu of Vaie'e. Lauaki's voice is just occasionally the clearest in a choir of strong voices, dressed as victim as well as agent. The story is about intervillage connections and traditional relationships. The historical narrative that represents this historical situation must needs be a fractured, twisting presentation of multiple individual and group histories. It must take account of swirling, incomplete adaptations.

Lauaki's voice in this long document is a less hectic, less confi- 
dently self-assertive voice than Solf's reports claim, more reflective in its slightly puzzled account of a complex, unfolding situation, seen through a glass darkly, with no clear beginning and uncertain ends. The gradually deteriorating relationship with the German regime emerges as a story of confusion and doubt on Lauaki's part-confusion at the contradictory signals from Mata'afa and other chiefs, doubt about how his actions would be interpreted by Solf. At every turn other voices are advising Lauaki, searching for a way to fulfill both traditional Samoan imperatives and remain within the borders of the new colonial law. His explanations, mediated though they are by Williams, remain plausible in our Western terms as well as in terms of his self-understanding. He is a player caught in a trap, driven by events, not driving them, limited in how far he could act as a free agent against both the colonial machine and the diverse agency of other Samoans. The pressure from Pule to go to Upolu and confront Solf was intense. Lauaki was their emblem, their spokesman. To deny Pule was difficult. "Death and exile in some foreign land is all alike to me, but my fear towards Faasalaleaga and Pule is hard" (Braisby $2: 168)$. The group rules, not the individual.

Likewise, the personal tussles with Solf are painted by Lauaki in a wider palette of colors than the black and white chosen by Solf. Solf's visit with his wife to Safotulafai was surrounded with traditional Samoan courtesies, feasts, and speeches of honor. Lauaki's speech was defensive, acknowledging that he had "committed adultery with thy spouse which is the tulafono (the Law)" (Braisby 3:325), and if he were to die it would be standing on the village malae, not in the forest or the ocean. The same sense of in-betweenness is present at Vaiusu, where-rather than aggressive challenges-the talk appears more a three-way discussion between Lauaki, Mata'afa, and Solf, with both Lauaki and Solf swearing oaths to affirm their words. One senses that Lauaki is under siege, as well he might have been because chiefs from hostile districts in Upolu were baying for his blood. Pagoa of Leulumoega and Molio'o of Faleapuna wanted him hanged (293). Even in his home district of Safotulafai, one of the most powerful chiefs, Leilua Taumei, was his committed opponent and kept Lauaki under virtual surveillance for Solf (Davidson 1976:296). In the end, Lauaki begged not to be sent away, "because I am afraid about all that. I will do everything that was stated. In your oath on the Bible [you said] that I am pardoned and that all Pule also is pardoned. All is at an end" (Braisby 3:338-340). 
Of course, a more attentive rereading of German and New Zealand records will not automatically deliver a revolutionary postcolonial history. But an awareness of the politics that have constructed the History and an openness to multivocal storytelling and to the unresolvable ambiguity in colonial encounters will help to identify the gaps and silences within "standard accounts." Lauaki's statement to Williams contains its own suspicious uncertainties. It was, after all, an interview in Samoan, transcribed and translated by Williams into written English. Nothing of the relationship between Williams and Lauaki inhabits the document, though Williams was known to have good relations with the chiefs of Safotulafai. Nothing is known of the place or the atmosphere or the dramatic performance that produced Lauaki's statement. Yet it is atypical of the documentation that surrounds and creates the History of the mau e pule. It is a long, conversational piece with none of the structuring of one of Solf's compressed reports to Berlin; it does not appear to be edited. It contains no easily identifiable rhythm, switching from event to person to place to issue, but there is a remorseless attention to issues that moved Samoans rather than those important to the German administration. It is full of signs rather than clear directions. This very ambiguity and disorder gives it a voice to challenge the confident analytical certainty of European judgements upon Lauaki and the movement identified with him.

And its construction of a Samoan story to rival the European is corroborated by the one Samoan written account of the mau e pule that has been carried down through the generations. In 1962, Tofa I'iga Pisa, Lauaki's lieutenant in 1909 and the last of his chiefly comrades left alive, wrote his own account of the mau e pule from the inside. I'iga Pisa's history was a story of affirmation and pride in Samoa's national struggle on the morning of her birth as a nation-state. It was designed to show how Samoans had always desired their independence, an independence grounded firmly in traditional custom and politics. Lauaki is the embodiment of that conservatism, his struggle a natural link in a chain that stretched from the time before Europeans arrived, all the way to 1962 (Pisa 1962; Hempenstall 1997). To that extent, I'iga Pisa's politics match those of the dominant History, reinforcing a continuous line of political development, even if his emphases are at the opposite end of the ideological spectrum. But I'iga Pisa's story also departs substantially from the canons of significance that European colonial and anticolonial tales adopt. His his- 
tory explores ancient district ties and family alliances stretching back to Samoa's "time of darkness" before the coming of Christianity. Lauaki emerges out of complex cultural and political events that only at points become enmeshed in European affairs. It is a history embroidered with poetry and powerful oratory, the elegies proclaimed at the death of great ones, the bravery of warriors in war.

Lauaki's lieutenant, with no guilt to exorcize half a century after the events, continues to insist that Lauaki was not the cause of the man e pule. He was the servant of Mata'afa Josefo and of his devotion to the Malietoa line. He was the victim of new chiefly power brokers collaborating with the German administration. Their names are scattered throughout I'iga Pisa's account-Leilua Taumei, Tuala Silivelio, Afamasaga Maua, Te'o Tuvale, Tolo Sooalo, Laupu'e, Moefaauo, Lelei Tavina. Lauaki is cornered by the onrush of events, his obedience to the great chiefs dubbed rebellion, and he is cast into exile as a sacrifice for the emerging Samoan nation.

Unfortunately, I'iga Pisa's rendition of events is not well known in Samoa and has never been published. In any case, we would be naive to accept his creation, or Lauaki's blandishments to Williams, at face value. Lauaki was not simply an honest broker between the districts who realized that his behavior was rebellion only when the warships arrived. There is evidence from Europeans and Samoans (Braisby 2: 174-88, 3:275; Solf 10.5.09; I'iga Pisa) that his challenge to Solf's control over Samoan politics had its roots in a decade of resistance to the pretensions of foreign powers and that he truly resented Solf's humiliation of Tumua and Pule since 1900. But if the stories of colonial encounters are told with all their messy entanglements, then agency and victimhood merge in the telling.

Samoans are not the only people whose stories need retelling. Wilhelm Solf, too, was entangled in the webs of meaning connecting Samoan district politics and the colonial culture that he embodied. Though he presented himself to his Berlin masters as the keystone of a successful, nonviolent "native policy," Solf was not the master of his own destiny in wrestling with Samoan aspirations. That his contest with Lauaki and others lasted over more than three months of meetings, letter writing, and tortuous maneuverings demonstrates that Solf had to be careful. He could not simply pluck Lauaki from his defenders but had to seek to keep the peace among many parties, leaving Lauaki to keep the peace in his own domains. Solf admitted to a friend that he and his aide had been genuinely terrified during the meeting in Vaiusu. Memories flashed through both their minds of 
a German district officer in South-West Africa who in 1904 was shot in the back in just such a gathering as he bargained to keep the peace before the colonial war that decimated the Herero (Solf to Schnee 3.6.09, file 131, Solf papers). Solf's rhetoric may have been effective in Vaiusu, but it began in panic-not in the confident swagger that went with the moral power of the colonizers. It was justified panic, for Samoan witnesses testified that hostile chiefs were ready to kill him, or let him be killed by the crowd, had they not perceived that he gave in to Lauaki by swearing on the Bible (Braisby 2:193). And if the threat of general insurrection were not enough to occupy him, Solf had also to protect his back against the knives of settler colonials in both Samoa and Germany.

Solf's European colleagues were the third element of an already complex equation, a roll call of businessmen, planters, and drifters described in Solf's jaundiced reports as slanderers, drunkards deranged by tropical influences, morally degenerate and dangerous. Solf's conviction that these people were seditious collaborators in Lauaki's movement was another simplicity. The Samoan community had shown ample proof that it would use disaffected Europeans for its own political and commercial ends (Hempenstall 1978: 49, 64-65).

The "messy" stories that complicate the histories of Samoa contain equally ambivalent accounts of the settler community. The settler community was riven by its own conflicts and contradictions, full of accusation and counteraccusation about complicity with the Samoans and attempts to discomfort Solf (Braisby 1:62, 75-80). A heart of darkness shadowed their racist and moral feelings of superiority over the "natives." Like George Orwell's protagonist, Flory, in Burmese Days, the Europeans feared that they were living a lie, trapped in and yet irrevocably part of an alien, hated land, pursued by their "slimy white man's burden humbug" (Orwell 1967:39). The potential to be defiled by the savage was never far from the surface of their anxieties, heightened in Samoa by the settlers' ambivalence toward a large and powerful mixed-race community that both repelled and attracted. The colonizing community was haunted by the fear that "the colonizer would not remake a colonized space but be remade himself as a native" (Thomas 1994:167). Solf himself spoke these fears for himself and others in his reports on the small settlers (e.g., Solf to Reichskolonialamt 1.11.07, RKA 2953). This anger with one another needs its stories as well. 
Historicizing colonial encounters for the present demands not the discovery of hidden caches of documents, but the releasing of voices that were previously muted or ignored (including that of the author), so that the storytelling that is history attains a fresh honesty and richness. The History of colonialism that has dominated renderings of the Samoan past assigned definitive identities to selected individuals and encompassed the history of colonialism within the boundaries of their constructed conflicts, conflicts rehearsed and repeated through generations of interpretation. Solf had indeed attempted to obliterate from the discourse that he established about Lauaki any memory of an alternative tale, not only by ignoring Lauaki's own version in his reports, but by buying up every negative of every photograph of Lauaki and his exiled comrades and having them destroyed (Braisby $2: 237,3: 377)$. This made it easier for an official account of the maue pule to triumph and for it to develop, with changes in the politics of historiography on Samoa, into the history of Lauaki as the harbinger of independence, the freedom fighter and protonationalist. And it explains why Lauaki comes down to us in History as a series of gestures only.

The creation of spaces where other voices can be heard creates alternative histories, more inclusive histories. Other individuals emerge and the chosen protagonists of the History, like Lauaki, become less visible, more tentative, always becoming caught in other people's struggles as much as fashioning their own world. Whole groups previously invisible also claim an identity so that the story of intercultural encounters becomes more untidy and ambiguous. Was the mau e pule an Olympian contest between two men or a mass movement, as is often simply assumed by historians because of the number of faceless Samoans who figure in the records as supporters of one side or another? Were large groups really involved or just spectators of a drama about colonial power that brought some interest into their lives? Was it an anti-German independence struggle or a purely Samoan movement that got out of hand, something that Braisby, under the pressure of the 1920s mau, claimed could be explained via the Samoan psyche and its tendency to recycle a limited stock of political ideas at regular intervals $(3: 338)$ ?

Why not all of these things in unequal measure? Conspiracy and accident, the same people agents and bystanders, perpetrators and victims. Perhaps no one could say ultimately how the drama would turn out. The Germans had the power to map distinctive relationships 
of power with their subjects, to peg out claims to authority and deference. But spaces remained in between for twists of the plot, for resistance and autonomy, for traditional imperatives and assertions of independence. The identity of the colonizers was a less confident and more ambivalent thing than they would have us believe from their stories, while the colonized did not adhere to the identities assigned them by these same stories. As Johannes Fabian says, why not allow human beings to be normal and crazy at the same time (1991:67)? A critical storytelling history that recognizes its own politics can make such allowances-and in the telling be both explanation and art.

\section{Notes}

1. Examples include Barker 1985; Biersack 1991; Fabian 1991; Gates 1985; Linnekin 1991b; O’Brien and Roseberry 1991; Pratt 1992; Roseberry 1989; Thomas 1994.

2. A crucial element of that storytelling on the part of historians is to determine what happened, not just why it happened. It is in this context that they must attend diligently, indeed obsessively, to the nature and range of evidences available to the telling. Other considerations also lie heavily upon the historian's work, such as what makes some events, structures, and people of historic significance and not others, the description and evaluation of context around the events and persons under interrogation, the searching for recurrent patterns as part of the narrative explanation, and the rhetorical functions of presenting a tale that is persuasive to one's audience. This is a task more comprehensive than a mere analysis of cause and effect.

3. Campbell sees this engagement as a dialectical struggle, a phrase I deliberately wish to avoid because of its constrained, Western, binary assumptions about the human condition across cultures.

4. The phrase is taken from the title of a session at the 1994 Pacific History Association conference in Kiribati, which explored the ambiguities of colonial encounters. The proceedings were published as Messy Entanglements, edited by Alaima Talu and Max Quanchi (Brisbane: Pacific History Association, 1995). 